\title{
7 Absence and presence
}

\author{
Introduction: existential contexts
}

In the final pages of his autobiography, No-one (1985), Thomas comments that

Our image of God must be transformed, as Bishop Robinson has said. The Church has up to this day produced a great number of thinkers of the quality of Paul and Augustine and Thomas Aquinas and Pascal. But somehow the alternative element in Christianity, the popular, somewhat sentimental element, has displaced the other, with unfortunate consequences to say the least. (107)

The reference to Bishop Robinson in these lines is to his influential bestseller Honest to God (1963). The 'transformation' which Robinson argues for, and which Thomas in the quotation endorses, is essentially from a 'deistic' to a 'theistic' understanding and imaging of divinity, that is, from an 'impersonal' to a 'personal' God. Of the deistic conception Robinson writes:

Here God is the supreme Being, the grand Architect, who exists somewhere out beyond the world - like a rich aunt in Australia who started it all going, periodically intervenes in its running, and generally gives evidence of his benevolent interest in it. (30)

Robinson juxtaposes this deistic conception of a remote God to an alternatively theistic divinity, a being not impersonal but intimate, a God of relationship:

The difference between the two ways of thought can perhaps best be expressed by asking what is meant by speaking of a personal God. Theism ... understands by this a supreme Person, a self-existent subject of infinite goodness and power, who enters into a relationship with us comparable with that of one human personality with another. (48)

This shift from an understanding of divinity as impersonal to an understanding of it as personal comprises half of Robinson's argument in 
Honest to God. In conjunction with it he also calls for a topographical or directional shift in popular theological imagery from a God 'up there' or 'out there' to a ubiquitous divinity which pervades the created world and, as such, is also distinctly interior. Thus the shift is from an impersonal divinity 'out there' to a divinity realised in relationship, 'in here'. In this second 'phase' of topographical or directional transformation Robinson leans heavily on ideas set out by the existentialist theologian Paul Tillich in his The Shaking of the Foundations (1949). In particular Robinson employs Tillich's image of divinity as a 'ground of being': "God, Tillich was saying, is not a projection "out there", an Other beyond the skies, of whose existence we have to convince ourselves, but the Ground of our very being' (1963: 22).

In a more precise articulation of this idea of divinity as an intimate 'ground of being' Robinson goes on to state that

God is not 'out there'. He is in Bonhoeffer's words 'the "beyond" in the midst of life', a depth of reality reached 'not on the borders of life but at its centre', not by any flight of the alone to the alone, but, in Kierkegaard's fine phrase, by a 'deeper immersion in existence'. (47)

I am emphasising Robinson's argument, and his references to Tillich, Bonhoeffer, and Kierkegaard, not only to contextualise Thomas theologically but, more in particular, to account for a remarkably similar 'transformation' which occurs between Thomas's mythic poems and those I have designated via negativa. ${ }^{1}$ As we have seen, Thomas's mythic poems reflect primarily a deistic understanding, that is, they set forth a distant and, for the most part, impersonal creator-God. In partial contrast to Robinson, Thomas's deistic divinity expresses wrath as well as divine compassion, but my point here is that whatever the nature of these expressions they occur across significant distances, allowing for little, if any, closer integration between creator and created. Alongside Thomas's mythic poems however, one encounters others in which the poet is clearly seeking out the possibility of a theistic God, a God not 'out there' and separate but 'in here' and intimate, whose presence is ubiquitous and therefore as much interior as exterior, Tillich's 'ground of being', whose defining characteristic is the desire for relationship. In a 1983 radio interview, R. S. Thomas at Seventy, the poet acknowledges Tillich as influential to his thinking: 'I do like Tillich's idea of the Ground of Being, that God is not a being' (178). But there is a subtlety here which needs to be noted. While Robinson argues for the 'ground of being' as a move towards a personal God of relationship, Thomas emphasises the phrase 
as indicating that God is not a 'being' at all. This is important to an understanding of Thomas's approach in these 'via negativa' poems. God, for Thomas, does become personal, but primarily in the sense of being non-anthropomorphic. While images of God become, for Thomas, radically interior and intimate, they remain images of a God of which, as he says, 'personality is only one aspect'. Thomas states in the interview:

we have been brought up on the Bible to believe that God is a Being, whereas the slightly more impersonal approach of Hindu thought, and Buddhistic thought for that matter, does give me a feeling that this is more what I am after. If there is any contact with an eternal reality I don't want to limit that reality to personality. It is a bit like Wordsworth's Fourteenth book of The Prelude with his trip up Yr Wyddfa, Snowdon. It seemed to me a type of majestic intellect. (178)

The shift one encounters between the God of the mythic poems and that of the via negativa poems is a shift primarily from the deistic paradigm of an anthropomorphised creator-God which is 'out there' to a ground of being, a 'majestic intellect', an eternal reality which is interior but unlimited, which is intimately personal, but which, as a ubiquitous source, simultaneously spills the boundaries of 'personality' or 'being'. J. P. Ward, in his The Poetry of R. S. Thomas, sees this shift as culminating in the collection Frequencies, which I shall examine shortly, where 'the writing becomes not a description of God, but a search for God' (83).

Finally, Robinson avows that Tillich's words 'seemed to speak of God with a new and indestructible relevance and made the traditional language of a God that came in from outside both remote and artificial' (22). In contrast to Robinson here, it is important to stress that, for Thomas, the 'discovery' of an understanding of deity as interior in the via negativa poems does not constitute a rejection of the mythic mode as erroneous, or even a progression forwards from it. The via negativa poems are not to be seen in contrast to the mythic poems, not as displacing them, but as distinctly complementary to them, as an ongoing exploration or expansion of deity as complex and multi-dimensional. Where the mythic poems are primarily intellectual speculations on the nature of an omniscient creator-God, the via negativa poems explore that same God as simultaneously 'subterranean' as it were, a ubiquitous, mystical divinity intuited within the more subtle nuances of interior presence and absence. While one can detect in Thomas's religious poems a 'progression', primarily in their imaging of divinity, this progression is 
towards an expanded conception of deity in which each of the 'successive' elements or aspects remains equally important, held in a reciprocal tension. More important than their 'progression', the mythic, via negativa, and via affirmativa poems can be seen to establish by such reciprocity a single, unified entity in which no 'type' is diminished, much less replaced, by the emergence or apparent counter-action of another. Together the poems comprise an exploration of the complexity and paradox inherent to the poet's growing apprehensions of deity. ${ }^{2}$

I will turn now to an examination of Thomas's yearning for and probing after such a theistic God by looking closely at the poems I have designated via negativa. In the final section of the chapter I will turn to look at poems which, in contrast to the predominant sense of absence which characterises the 'via negativa' poems, indicate a more positive realisation of that theistic God, depicting divinity not as absence and darkness but as renewed presence or light, an actuality no longer to be inferred.

\section{Via negativa: Frequencies and absence}

Via negativa, meaning literally 'by way of what is not', is an idea associated largely with mystical theology. Thomas himself uses the term as a poem title in $H^{\prime} m$. Perhaps the earliest and most comprehensive discussion of via negativa occurs in 'The Mystic Theology', the work of the sixth-century Syrian mystic Dionysus the Areopagite, although the idea is perhaps best known in the West through the anonymous English classic of medieval mysticism The Cloud of Unknowing. Regardless of particular sources, the idea of via negativa is common to eastern mystical traditions predating Christianity, as well as to Christian monastic traditions in the West, both as an approach to and as an experience of divinity. As a technique of approach via negativa signifies a deliberate mortification not only of the sensual appetites but of the whole desire of the ego for its own realisation and dominance, as well as of the distraction seen to be posed by the physical world. It insists upon an emptying of the self, a silencing of the individual will, and a patient waiting and watching in these privations for God's approach. For example, in 'The Flower' from his 1975 collection Laboratories of the Spirit, Thomas writes:

I asked for riches.

You gave me the earth, the sea, the immensity

of the broad sky. I looked at them 
and learned I must withdraw

to possess them. I gave my eyes

and my ears, and dwelt

in a soundless darkness

in the shadow

of your regard.

The soul

grew in me, filling me

with its fragrance. (25)

The register of these lines is clearly that of the via negativa, an ascetic withdrawal, the giving up of sight and sound, the dwelling in darkness and shadow. And yet Thomas makes it clear in the opening lines of the poem that such withdrawals, in keeping with the via negativa as a technique of approach, are embraced solely in pursuit of spiritual 'riches', a kind of mystical union with the divine. It needs to be emphasised, however, that the actual experience of the divine is not always one of such presence but frequently, rather, of absence. This experience of divinity as absence is rooted in a philosophical logic which asserts that since divinity, by its very nature, must necessarily overflow the created world of the senses, its presence therefore, at least in the higher realms of contemplative prayer, must, paradoxically, be expressed in terms of that which is not, as an actuality to be inferred from the experience of absence. Ward, in his chapter entitled 'God Absent and Present', describes this via negativa absence as 'itself an entity, as implying of necessity a presence before, after or beside, by which the resulting absence could have pressure, and seem to hint at something not itself, and so not be mere flat emptiness' (1987: 97). Later in the same chapter Ward writes: 'We can never conceive "nothing" without the outline of a shimmering shape which suggests what has been removed' (105). Thomas's poem entitled 'Via Negativa', from the collection H'm, is a good example of this, depicting the sensation of painful absence as itself indicative of divine presence. Thomas writes:

Why no! I never thought other than

That God is the great absence

In our lives, the empty silence

Within, the place where we go

Seeking, not in hope to

Arrive or find. He keeps the interstices

In our knowledge, the darkness

Between stars. His are the echoes 
We follow, the footprints he has just

Left. We put our hands in

His side hoping to find

It warm. We look at people

And places as though he had looked

At them, too; but miss the reflection. (16)

The absence in these lines is clearly haunted, pregnant with a very distinct, albeit intangible, sense of presence. One notices how the is of God's existence in line 2 is an 'absence', an 'empty silence', the elusive 'place', the 'darkness / Between stars', 'echoes', 'footprints', missed 'reflections'. The experience of divinity in these lines can be seen to be predicated upon the sense and signs of absence. God here must be inferred from what is not. It should be emphasised too, however, that the via negativa experience of divinity's painful absence is often seen to be tied to the idea of purification, both as the winnowing of a sense-orientated framework inadequate to the fuller apprehension of that which radically transcends all sense experience, and as the gradual purgation of an unworthiness wrought by sin, both of which seem to be a part of what St John of the Cross refers to as 'the dark night of the soul'. Equally, such via negativa experiences of absence are often considered a kind of protection against a divine brilliance too powerful to be unmediated, the deep shadow thrown by blinding light, what Vaughan refers to in his poem 'The Night' as the 'dazzling darkness' of the divine. Most importantly however, in all of these various aspects the via negativa is to be seen as an experience, even as a diatonic or recurring 'stage', common to prolonged spiritual pursuit, an acceptance of darkness and unknowing in a spiritual journey towards the realisation of what Thomas calls 'ultimate reality' or, in Tillich's phrase, 'the ground of being'.

Like the mythic poems, the via negativa poems begin to appear with the volume $H^{\prime} m$ in 1972. But if $H^{\prime} m$ represents the most intensive treatment of the mythic poems, it is the 1978 collection Frequencies which manifests most widely Thomas's preoccupation with the idea of the via negativa as an experience of deity. In turning now to examine these poems in Frequencies I want to stress again that the mythic and the via negativa poems occur side by side, that they are contemporaneous and, as such, should not be seen so much as definite 'stages' in a strict theological development by Thomas but, rather, as manifestations of the poet's deepening spiritual probe, his grappling with the nature of deity and its relation to human experience. The title, Frequencies, itself indicates a widening range to the poet's probe of divinity, pointing to an 
awareness of spiritual 'vibrations' or 'signals' coming simultaneously from distances without and within. Far from being disposed of, the mythic God is still very much the God of Frequencies as, for example, in 'The Gap', 'The Woman', and 'Play'. Still, with Frequencies there occurs a subtle shift away from contemplations of the mythic creator-God towards the possibility of a more intimate or interior divinity. For example, in 'Groping', the fifth poem in the collection, Thomas is writing not of cosmic explorations of a vast God-space beyond but of a journey within the self, the exploration of divinity within an interior landscape:

Moving away is only to the boundaries
of the self. Better to stay here,
I said, leaving the horizons
clear. The best journey to make
is inward. It is the interior
that calls. Eliot heard it.
Wordsworth turned from the great hills
of the north to the precipice
of his own mind. (12)

Thomas, in these lines, seems to have put away, at least temporarily, the mythic creator-God as a vehicle for his intellectualised handling of theological suppositions in favour of a more emotional or intuitive approach to God as a personal 'ground of being'. In contrast to the mythic poems, one senses little irony here but, rather, a gentle transitioning away from probes upward and outward to probes downward and inward, to the possibility of deity within 'the boundaries / of the self'.

Thomas reiterates this shift more explicitly in the final poem from Frequencies, 'Pilgrimages'. Both titles, 'Groping' and 'Pilgrimages', suggest action and movement, but with the added implication of a released intellectual tenacity, action characterised by an inherent receptivity. The search goes on in these poems, but in a changed direction, and with an emphasis placed not so much on the goal of empirical knowledge as on the possibility of intuited understanding. For example, Thomas writes in the first stanza of 'Pilgrimages':

He is such a fast

God, always before us and leaving as we arrive. (51)

This is the mythic creator-God, at large in cosmic space, with the narrator in frustrated pursuit. However, as if exhausted by such outward and grasping pursuit, Thomas writes in the poem's final lines: 


\author{
Was the pilgrimage \\ I made to come to my own \\ self, to learn that in times \\ like these and for one like me \\ God will never be plain and \\ out there, but dark rather and \\ inexplicable, as though he were in here? (52)
}

The inference here is not that the mythic probings of a creator-God were fruitless, but that they have led, finally, to the prospect not of a 'plain' God 'out there', but of a 'dark' God, 'inexplicable' and 'in here'. One senses in these lines not merely a metaphorical shift in 'direction' but a fundamental shift in ethos from an irony characteristic of the mythic poems such as 'The Island' to a posture of genuine relaxation, even surrender, a movement from the active to the passive, from a muscular intellectual ordering to a more accepting humility. ${ }^{3}$

As I have already indicated, Thomas's depictions of the via negativa are primarily concerned with the experience of absence rather than with the technique of asceticism. Although he does write of the ascetic's approach to deity, most notably in 'The Flower' and 'Sea Watching', both from Laboratories of the Spirit (1975), Frequencies is a record of the via negativa primarily as experience. This is not to say that Thomas's search for a theistic or relational God is frustrated but, rather, that it results in the paradoxical affirmation of absence as the predominant experience of divine presence. While 'Via Negativa' from H' $m$ is probably the single most explicit elucidation by Thomas of that experience of divinity as absence, its echoes go on to pervade the poems of Frequencies. For example, we have seen already how in 'Via Negativa' the presence of divinity becomes predicated upon signs of its absence. This motif begins to predominate in the poems from Frequencies. In the first stanza of 'The Possession' Thomas writes:

$\mathrm{He}$ is a religious man.

How often I have heard him say, looking around him with his worried eyes at the emptiness: There must be something. (33)

While these lines reflect an outward probing characteristic of the mythic poems, the protagonist's experience of 'the emptiness' shows the via negativa clearly at work. In particular, while the illocutionary force of the statement 'There must be something' is indicative of despair, that is, of a realisation that, indeed, there $i$ nothing, it may also be read as the affirmative corollary to the experience of 'the emptiness' which 
directly precedes it. According to this latter reading, the exclamation 'There must be something' can be taken literally. It is possible and, given the poem 'Via Negativa', very probable that the experience of emptiness in these lines is, in part and paradoxically, a catalyst to the affirmation of 'something' in the final phrase. Similarly, in the poem 'Abercuawg' Thomas writes:

An absence is how we become surer of what we want. (26)

Thomas's play on the word 'want' in these lines indicates it to signify both 'desire' and 'lack', and by this expansion he seems to be suggesting that the experience of absence is not only the way in which 'we become surer' of what we desire and what we need, but that, in a paradoxical way, it is precisely the absence which makes those objects real. They exist because they are not. Predating the poem, but co-textual with it, is Thomas's 1976 National Eisteddfod address of the same title in which he expands on this idea, linking it to the creative process:

Here is no cause for disappointment and despair, but rather a way to come to know better, through its absence, the nature of the place which we seek. How else does a poet create a poem other than by searching for the word which is already in his mind but which has not yet reached his tongue? And only through trying word after word does he finally discover the right one. This is certainly not an example of emptiness, but of becoming. (172)

The comparison here between the poet's search for the word and the poem and the individual's search for God is rich with implication. For Thomas, divinity, like the poem, exists in its absence, somewhere between the mind and the tongue. It is precisely in and through such absence that Thomas claims one comes to know better the nature of that divinity. However, and this is my main point here, like the poem, that 'better knowing' does not emerge to a static passivity, but under the constant pressure of absence, a tension between the mind and tongue according to which the individual seeks relentlessly for an opening, for the right word as it were. In this way the realisation of reality, its dynamic 'becoming', is linked inextricably to the most powerful work of imagination. Thomas does not question the fundamental actuality of the divine or of the poem but, rather, the ability of the individual, through imagination, to realise or create the existence of each according to its absence. This is the root of the paradox out of which the via negativa emerges, and I shall turn now to the poems 'Shadows', 'Adjustments' 
and 'The Absence', all from Frequencies, in order to examine it more closely.

Thomas writes in 'Shadows':

I close my eyes.

The darkness implies your presence, the shadow of your steep mind on my world. I shiver in it.

It is not your light that can blind us; it is the splendour of your darkness. (25)

It is the narrator's rejection of the sensory world in line 1 which creates the darkness in which presence becomes immediately implied so that shadow, an important motif in Thomas's poetry, becomes suddenly blinding by its splendour. This of course is paradoxical - the blinding splendour of shadow - blinding not by obscurity but by splendour or brightness. Shadow is in fact both the product of light and its opposite, that is, blocked light or darkness. In these lines, however, that blocked light retains, paradoxically, the radiance of its source. Meaning here overflows language. Thomas continues:

And so I listen

instead and hear the language

of silence, the sentence

without an end. (25)

These lines too find their centre in apparent contradiction. Just as in the first quotation light dwells in darkness, here sound exists in silence. It becomes clear that the discourse of the via negativa is one in which words are continually denied their usual associations, in which language itself is 'broken open' to accommodate the possibility of its opposite value in paradox, a clear parallel to Derridean différance.

The poem 'Adjustments' reiterates this idea, central to the via negativa, in its opening lines:

Never known as anything

but an absence, I dare not name him

as God. (29)

Here we find not only a breaking open of language into paradox but an actual mistrust of language by the narrator as an inadequate signifier of 
meaning. The poem's title, 'Adjustments', is, in part, a reference to this inadequacy of language and the need to relinquish a more traditional or 'logocentric' understanding of the word. Ben Astley, in his 1998 article "“Somewhere Between Faith and Doubt": R. S. Thomas and the Poetry of Theology Deconstructed', sees this 'breaking open' of language as a manifestation in Thomas's work of 'Derridean deconstruction' in which 'the free-play of the sign destroys any attempt to reduce or restrict the associations of the sign' (77). While this seems true, it should be noted that in the discourse of the via negativa the word becomes an approximation, often more accurate in its cataloguing of what a thing, in this case deity, is not, rather than of what a thing $i$ s. The 'free-play of the sign' is indeed achieved, but within a negative context. This alarming re-interpretation of the function of language can be viewed not only as a challenge to the 'tyranny' of the word, freeing meaning from the constriction of a rigid signifier, but as a movement by Thomas towards a moral stance of receptive humility. For example, he writes:
Patiently with invisible structures
he builds, and as patiently
we must pray, surrendering the ordering
of the ingredients to a wisdom that
is beyond our own. We must change the mood
to the passive.

These lines assert the need for a changed stance in relation to both language and philosophy, a stance open to meaning as transcendent of the word and of the reason, meaning as overflowing vocabulary and logic, not to be dictated by the wilful administrations of language and rationality but, rather, received, accepted as larger than both. The movement here is towards a mystical or intuitive awareness as superior to a purely rationalistic understanding. Thomas is emphasising in these poems what he calls in 'Via Negativa' 'the interstices / In our knowledge', that is, the 'gaps' in a rational understanding, not necessarily as a hindrance, but as the actual path towards an increased awareness of deity, a 'knowledge' which defies the expressive capabilities of language. The 'interstices' of 'Via Negativa' become the 'invisible structures' of 'Adjustments'.

This emphasis on absence as presence, on the inability of language to encompass meaning fully, and on the failures of rationalistic thought to comprehend the divine are all, finally, the subject of the poem 'The Absence'. Thomas writes: 
It is this great absence

that is like a presence, that compels

me to address it without hope

of a reply. (48)

Here again, we find Thomas's opening statement to be an affirmation of the via negativa. Linked to this affirmation we find a corresponding mistrust of language by the poet. Not only does the experience of divinity as absence warn Thomas against hoping for a 'reply' to his address, thus further acclimatising him to the medium of silence, but twice in these lines Thomas refers to deity as 'it', further evidence that, for him, language must fail in its most fundamental purpose of naming. He goes on to elongate the description of absence in these lines into the image of an empty room:

\section{It is a room I enter}

from which someone has just gone, the vestibule the arrival of one who has not yet come.

Again, in contrast to the mythic poems, absence in these lines is depicted not as 'out there', in realms of space, but 'in here', as an interior and domestic absence, like 'a room I enter'. In keeping with that image, the hoped-for divinity in these lines, while still anthropomorphised, is imaged as relational, as someone who has just left or who has yet to arrive, as an intimate self or relation of the self. This interiority of absence, and intimacy of a longed-for divinity, are further indications of Thomas's shift in these via negativa poems from a predominantly deistic understanding of an exterior creator-God, to a predominantly theistic understanding of an interior 'ground of being'. Thomas goes on in 'The Absence' to implicate both language and science as incapable of 'inverting' the paradox of the via negativa:

I modernise the anachronism

of my language, but he is no more here

than before. Genes and molecules

have no more power to call

him up ...

$$
\text { My equations fail }
$$

as my words do. 
In these lines scientific knowledge fails as a 'corrective' to the paradoxical nature of the via negativa, that is, science fails to make absence as absence and presence as presence. In the face of scientific advancements towards an expanded knowledge of 'genes', 'molecules', and 'equations', the paradox of the via negativa persists. What Thomas seems to be suggesting in 'The Absence' is, first, that deity exists; second, that it can be posited and apprehended on the basis of its absence; and, third, that it continually overflows the rational confines of both language and science. Ultimately, these recurring characteristics of the via negativa are employed by Thomas effectively to undermine the exclusivity of rational thought as a ruling discourse by affirming the necessity, at least regarding the search for deity, of a mystical approach and an intuited understanding. The final statement of 'The Absence' is explicit in its expression of this:

\section{What resources have I}

other than the emptiness without him of my whole being, a vacuum he may not abhor?

The question is, of course, rhetorical, Thomas's answer being 'none'. Where language and science fail as 'resources' in the narrator's search for divinity, there remains only the experience of emptiness and the inference of an imagined fullness which can be drawn from it. In the poem's final line Thomas plays on the notion that 'nature abhors a vacuum' by holding up the tension, central to the via negativa position, between the enduring existence of that vacuum and yet, according to this 'law', the immanent filling of the vacuum by presence. Thus, the via negativa, for Thomas, balances between the emptiness of absence and the fullness of expectation. And it is within that carefully balanced tension and its engendered waiting 'on that lean / threshold, neither outside nor in' that, according to the via negativa experience, deity is finally located (10). Such waiting in tension is in keeping with the Kierkegaardian existentialism often associated with Thomas. For example, D. Z. Phillips, in his book R. S. Thomas: Poet of the Hidden God (1986), argues that the poet, after rejecting, like Hume's Philo, the 'Argument from Design' for God's existence, embraces in the via negativa not only an existentialist angst but an existentialist freedom as well:

We come to God through a via negativa, by coming to see that the nature of his will is born not of an external system which gives a point to everything, but of a radical pointlessness in things. It is 
precisely because there is no reason why things should go as they do in life that there is a possibility of seeing all things as acts of grace ... It is not by seeking explicit answers, but by seeing why such answers must be hidden, died to, that the possibility of belief in a God who is present in all things emerges. (82)

Not only is such 'dying' to a need for answers a characteristically existentialist position held by Thomas, it is at just this point of dying, and by way of such dying, that patience, stillness, and waiting become, for Thomas, the keys to an interior freedom, to a 'grace' which Phillips calls 'the givenness of things under a religious aspect' (87).

It is important to note that, for Thomas, depictions of absence associated with the via negativa frequently give way to, or are countered by, depictions of affirmation and spiritual presence. J. P. Ward writes that 'The God who eludes when all palpable things, even the senses themselves, are left behind, can suddenly be experienced in what is immediate and natural' (1987: 98).

Remembering Elaine Shepherd's description of the via negativa as 'a darkness which may on occasion ... flame with love', I will end this chapter by turning to examine such 'occasions' in Thomas's work, and by suggesting that they constitute, by their increasing frequency, the most recent 'phase' in the poet's spiritual journey (1996: 186). At the same time that Thomas expands the category of 'religious poetry' to include spiritual doubt and the experience of absence, he also, albeit more quietly perhaps, makes his returns in the religious poems to a very traditional and, in many ways, Celtic spirituality of affirmation and presence. Esther De Waal, in her book Celtic Light: A Tradition Rediscovered (1997), underscores what she sees as a major characteristic of that spirituality. Writing of her experience of viewing the Celtic high crosses at Monasterboice, Ireland, she writes:

I was being confronted here for the first time with a starkly dramatic statement of what I was to find time and again as I came to understand better the Celtic way of seeing the world: this ability to hold things together. (7)

Later in the book she adds that

David Jones once said that the favourite phrase for any artist must be that of psalm 122 where Jerusalem is described as a city 'at unity in itself', and he added that in Welsh that word translates as interjoining, the crafting between the whole and the parts. (135) 
Together these two observations articulate an idea which I have already suggested is a central theme for R. S. Thomas: the struggle for wholeness. While critics often and rightly focus on the characteristic angst of Thomas's poems, on their stark realism and level, unflinching gaze, and while it is true that such angst is produced, in part at least, by the disparity between that realism and an ideal vision, this emphasis on realism risks ignoring the poet's 'ability to hold things together', his 'crafting between the whole and the parts'. Especially in the religious poems, Thomas not only explores the secular in its relation to the sacred, but succeeds in re-contextualising the secular within the sacred. He is at pains in the poetry as a whole, but in particular in the religious poetry, to express the beauty and wholeness of the world as well as its brokenness and division, the redemption of humankind as well as its demise, belonging as well as alienation. Moreover, for Thomas, these opposites are often to be found within each other as elements in a larger whole. This idea of wholeness forms the foundation for A. M. Allchin's important book Praise Above All: Discovering the Welsh Tradition (1991). Like De Waal, Allchin (himself a Thomas scholar) also claims that at the heart of much Celtic poetry, both old and new, is

a protest against a whole Christian culture, Latin and to some degree Greek, which rather sharply divides sacred from secular, priestly from poetic, grace from nature and God from humanity, on behalf of a world view which sees these things as very closely interrelated in ways which sometimes fascinate us and sometimes disconcert us. (10)

Such interrelation, although seemingly paradoxical, is rarely contradictory within this wider frame of reference to an ancient world-view in which the material and the spiritual were one. The creation of art, for Thomas, is nothing less than the fruit of this ancient impulse and struggle to knit two worlds together, to reconcile reality and the dream into a synthesis of wholeness. ${ }^{4}$ Although that impulse and struggle may seem to form a quieter subtext in the poems, it is also foundational to them, a characterisitc which Thomas inherits more recently from Blake, and one which he shares with his contemporary Dylan Thomas. ${ }^{5}$ All three poets depict the possibility of the physical and spiritual regeneration of the modern world through the realisation and application of a vision in which the dualities and divisions they perceive in contemporary urban or industrial life are re-incorporated through imagination and art into an original whole. R. S. Thomas is not only a poet who poses bleak dilemmas but one who, at times, offers 'answers' to those dilemmas which are 
characterised by an ancient simplicity, and which seek, ultimately, to reconstruct the world by 'crafting between the whole and parts'. In this, as well as in his continual affirmation of the practice of silence and waiting, Thomas makes his returns in poetry to a spiritual grounding which enables him, especially in the later poems, to voice an increasing resiliency and hope. ${ }^{6}$

The poem 'Groping' (Frequencies, 1978), which I have pointed to already as indicative of a shift towards interior explorations of deity as a 'ground of being', is a good example of the via negativa experience giving way to an experience of presence. In the poem's second stanza Thomas describes the inward search for divinity:

For some

it is all darkness; for me too, it is dark. (12)

While this is a classic description by Thomas of the via negativa experience, he goes on to complete the stanza, and the poem, with a qualification of the experience of darkness as punctuated by experiences of presence:

\section{But there are hands}

there I can take, voices to hear

solider than the echoes

without. And sometimes a strange light

shines, purer than the moon,

casting no shadow.

The images employed in these lines stand in direct contrast to the images we have already examined in the poem 'Via Negativa'. Here, absence is replaced by hands, silence by voices 'solider than the echoes / without', darkness by 'a strange light' which casts no shadow. In contrast to the blocked light, the paradoxically radiant dark, to take up Vaughan's image again, of the poem 'Shadows', here we find the light is pure, unimpeded, presence not as absence but as itself, as Thomas emerges from the mere inference of deity through absence to its actual realisation. We find this same kind of epiphanous presence depicted in 'The Answer', also from Frequencies:

There have been times

when, after long on my knees in a cold chancel, a stone has rolled from my mind, and I have looked 
in and seen the old questions lie

folded and in a place

by themselves, like the piled

graveclothes of love's risen body. (46)

The phrase 'There have been times' clearly indicates that the experience of spiritual presence, of 'love's risen body' is recurring for the poet. What I want to emphasise here, however, is not merely its repetitive nature, but that the experience of presence here, as in 'Groping', comes 'after long on my knees', that is, as the culmination of a via negativa experience. Like Thomas's experiences of deity in nature, which I have examined in Chapter 4, these affirmativa experiences are punctuations, recurring flashes of light in which, as Thomas describes it in an allusion to Christ's resurrection in John 20.1-10, 'a stone has rolled from [the] mind'. In this interiorisation of the resurrection experience it is the 'old questions' rather than the graveclothes of the risen Christ which 'lie / folded and in a place / by themselves'. According to this configuration, Thomas's philosophical dilemmas concerning divinity have not ceased per se but, rather, have been punctured, effectively deflated in their significance by the poet's experience of 'love's risen body'. The nature of that experience remains undisclosed, a mystical experience which, again, defies the expressive capacities of language rooted in sense experience.

\section{Via affirmativa: Destinations and arrival}

New directions are nearly always subtle and difficult to pinpoint in $\mathrm{R}$. S. Thomas's work. He was a poet who worked his field, constantly making his returns, going slowly back over the old ground, relentlessly working and reworking the new into the old, producing shades, echoes, reflections. It is important to view Thomas's work less in terms of linear stages of development and more in terms of a deepening and often paradoxical complexity in which seemingly separate 'categories' of poems enjoy ongoing reciprocities of definition and meaning. Despite this, critics have sometimes sensed turning points in Thomas's work. For example, R. Gerallt Jones, in his review of the volume Later Poems (1983), claims that the poems in the 'New Poems' section of that volume articulate a 'more positive consciousness of a purposeful Creator in the observable phenomena of the universe as well as in the inner stirrings of the spirit' (1983: 10). Jones writes that the poems 'record ... a new stage in a spiritual journey', and that 'a new dimension is being added 
to the work of a major poet'. While Jones does not describe that 'new stage' in any detail, he does cite the poem 'Suddenly' which clearly expresses an intensity of affirmation largely absent from Thomas's work up to this point:

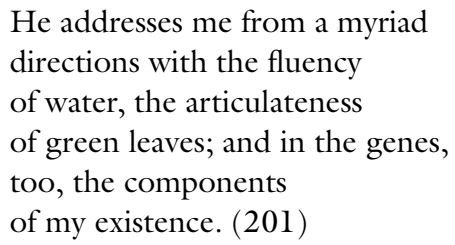

Thomas ends the poem, the cadence of which is breathless with presence, with a statement whose solidity of expression and lack of hesitation challenge all preconceived notions of him as the poet merely of bleak longing:

I have no need

to despair; as at

some second Pentecost

of a Gentile, I listen to the things

round me: weeds, stones, instruments,

the machine itself, all

speaking to me in the vernacular

of the purposes of One who is.

Similar evidence for the emergence of a more positive philosophical stance in Thomas's work might be discerned from the poems 'Caller' and 'Arrival', also from Later Poems.

In contrast to Jones's emphasis on Later Poems, A. M. Allchin, in his article 'Emerging: A Look at Some of R. S. Thomas' More Recent Poems' (1992), argues that it is not Later Poems but the 1975 volume Laboratories of the Spirit which represents a new strain of affirmation. Allchin cites primarily the poems 'Emerging' and 'Good', while suggesting traces of affirmation as early as H'm (1972). But again, such instances of affirmation in Thomas's work prior to 1985 remain relatively isolated and largely uncharacteristic. What Allchin's reading does re-affirm is that 'shifts' in Thomas's work are more often subtle and gradual. Although Later Poems (1983) and Laboratories of the Spirit (1975) do indicate the beginnings of a shift in Thomas's experience, they primarily foreshadow an affirmation which finds its fullest expression in the 1985 collection Destinations. Gathered in Destinations is the 
most substantial and explicit evidence of a gradual shift towards affirmation in Thomas's work. An exploration of that shift is vital to an understanding of the sometimes complex development of Thomas's poetic vision. In his 1993 article 'An Inexplicable Note of Hope', Allchin rightly suggests that, while Thomas's work is commonly renowned for pessimism and distress, such a view fails to realise the complexity of both the man and the work. He writes that

bleak is one of the most frequently employed words to describe R. S. Thomas's vision of the world and our human situation in it ... But here again we can be too absolute in our judgements. Much of what is commonly said about R. S. Thomas's work is true but is not the whole truth. (12)

Allchin concludes with the assertion that an

inexplicable note of hope grows stronger in R. S. Thomas's latest poetry. It is never the dominant note, never pushed forward blatantly in terms of preaching or propaganda, yet it remains obstinately there. (14)

Such a note of hope, and perhaps more particularly of acceptance, though it glimmers intermittently between H'm (1972) and Later Poems (1983), finds its most unified and powerful expression in Destinations. In the volumes which follow Destinations this expression of hope and acceptance, though less obviously dominant, more incorporated or 'worked in' to the existing fabric, remains vitally present as an ingrained characteristic. Destinations is the neglected mainspring of this philosophical turning towards affirmation in R. S. Thomas. ${ }^{7}$ The probings that begin with $H^{\prime} m$ are undoubtedly continued in subsequent volumes, but with less urgency, with greater confidence in a presence which, if still at times elusive, is both benevolent and purposeful. Thomas seems, by Destinations, to have evolved spiritually out of unfathomable space and the predominating experience of absence, not towards contentment or truce, but clearly into an expanded vision. That vision creates a gentle lightening of tone in much of the later poetry, a bleeding off of pressure, a calmness in waiting, out of which the sometimes paradoxical complexity and richness of much of his later work has been born.

'The Message', the first poem in Destinations, is similar in tone and attitude to 'Suddenly', cited already as an early expression of a new via positiva or via affirmativa approach for Thomas. One can hear the outbreaking of joy so uncharacteristic of the poet's past work: 
A message from God delivered by a bird at my window, offering friendship.

Listen. Such language!

Who said God was without speech? Every word an injection to make me smile. (7)

As in 'Suddenly', after long silence God becomes voluble for the poet. It is, of course, Thomas himself who suggests in 'Via Negativa' that God is without speech, but here the unequivocal message from God is that life is joy, not momentary or fleeting, but promised and enduring. 'Meet me', the bird continues,

tomorrow, here

at the same time and you will remember

how wonderful today was: no pain, no worry; irrelevant the mystery if unsolved.

Strangely, this is not one of Thomas's interior selves nor even nature speaking, but, indirectly, deity itself, teaching that 'the mystery' is irrelevant, that 'solving' is no longer of paramount importance. God goes on to tell Thomas that his gift as a poet, the 'X-ray eye', was given him not so much to search with but to search with and to discover 'the unmalignancy of love's / growth'. The poet is to see into the nature of things, under their surfaces, and find there not absence but love growing in place of disease. Here is a significant development in outlook when one considers that Thomas is a poet of search. Here he is instructed to turn aside from that search to vision and discovery.

The metaphor of the bird is central to the poem 'Vocabulary' as well:

\footnotetext{
Ruminations, illuminations!

Vocabulary, sing for me

in your cage of time,

restless on the bone's perch.

You are dust; then a bird

with new feathers, but always

beating at the mind's bars. (11)
} 
There is a conspicuous, almost alarming, absence of brooding here. The tone is positive and excited, ruminations giving way to exclamated illuminations. The poet remains undaunted by 'time's cage' even. The command is to 'sing' in the face of time's restrictive nature. Like the phoenix, vocabulary rises from its own dust and previous inadequacy to a newly feathered bird, resurrected to new life and vigour. In the conclusion to the poem Thomas calls himself a 'new Noah' and despatches the bird to alight on 'steel branches'. But instead of using the image of steel branches as an opening through which to introduce the long shadow of modern technology or 'the machine', as one might expect him to, Thomas, as the new Noah, calls the bird home to himself,

looking for the metallic gleam of a new poem in your bill.

There is no sarcasm in this, no bitter irony, but a surprising integration of the modern scientific world and the poet's visionary world. The allusion to Noah underscores the death of the old for Thomas, the 'flooding out' of an older order and, with it, the prospect of new beginnings.

One of the most powerful poems in the collection, the sonnet titled 'The Other', recounts a less exaggerated though perhaps far deeper rejoicing by Thomas. ${ }^{8}$ The title is a reference to deity characteristic of Thomas's via negativa stance of the 1970s: God is that which is not me and beyond naming. The poem contains other threads from Thomas's past work as well. There are the 'lean hours' in line 5 for example, the monotony of the waves, the village 'without light / and companionless', and, not least, God's ultimate silence (15). But despite all that, the whole ethos of the poem is one of peace and presence. In the still night the poet hears the small owl calling far off, and the miles-distant bark of the fox. He lies awake listening
to the swell born somewhere in the Atlantic rising and falling, rising and falling wave on wave on the long shore by the village, that is without light and companionless.

These distant voices, heard in the dark stillness, are the voices of a presence which, for Thomas, are almost always apprehended in the rhythms of the natural world. One notices the almost hypnotic repetition of present participial verbs in combination with the relentless 
heave of the sea: calling, barking, listening, rising, falling, rising, falling, wave on wave. It is from out of these rhythms that Thomas arrives at the turning point, the volta, the epiphany of the poem in which he realises

that other being who is awake, too, letting our prayers break on him, not like this for a few hours, but for days, years, for eternity.

Here, in the final four lines, the poem moves away from the natural to incorporate the divine and the human. Prayer becomes a part of the natural rhythm too, in league with the cry of the beasts and the crash of the surf, and endlessly acceptable to God. Thomas's sympathy for the song of nature becomes God's unsleeping sympathy for the song of nature, not the least part of which is now the prayer of humanity. Indeed, unity between Thomas, God, and nature has become a recurring motif in these poems. In 'The Message' God and Thomas 'connect' by way of the bird. In 'Vocabulary' the 'new Noah' emerges from floods of the spirit to receive poems from the bill of a vocabulary that was once dust, turned yet again into a feathered envoy from God. Now, in 'The Other', that unity comes to include God, nature, and not only Thomas himself but all humanity at prayer. It is 'our prayers' that break on God in line 12.

In 'He and She' and 'Mother and Child' Thomas goes on to explore the more particular unity of human love. In 'He and She' the close physical proximity of the two characters develops quickly into a spiritual intimacy that is itself a reflection of something eternal. Thomas encapsulates that gradually deepening presence in the five lines which begin the poem:

When he came in, she was there.

When she looked at him, he smiled. There were lights in time's wave breaking on an eternal shore. (23)

Here is an image of the meeting of time and eternity similar to the endless breaking of 'our prayers' on God in 'The Other'. Again in these lines, time is giving way to eternity under the influence of love. Through a crafted metaphor in the second stanza the man and woman converse noiselessly: 


\author{
Thoughts mingling \\ were lit up, gold \\ particles in the mind's stream.
}

But perhaps most startling is stanza three, in which Thomas describes the nature of human love as contingent not only upon an aggressive initiative by one but, equally, upon a willing reception of those advances by the other. One finds in the final line that the lovers have previously known failure in their repeated attempts to cross the treacherous 'fathoms' of the heart. Thomas highlights by this image of dangerous depths the delicacy of the love relationship, but also, and most importantly here, the poignancy and power of its success:

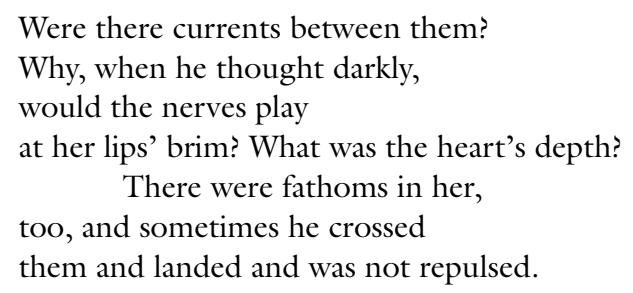

'He and She' demonstrates not only a keen insight into the precarious nature of human love but an equally keen awareness of its heroic possibility. That same optimism is confirmed again in 'Mother and Child', a portrait of human love before

\author{
that angled \\ event that from beyond \\ the horizon puts its roots
}

down. (26)

Despite the potent threat of impending evil in the 'breast's apple' for which the child reaches, and in the sleeping snake, this is not indulgence in a dream of some mythical past prior to sin. Thomas claims in the poem that 'this is Eden / over again', allowing a reading of the poem as an instance of momentary innocence, of temporary purity and of the infinitely repeatable victory, even if fleeting, of love over division and of innocence over corruption. Each of these poems has, as its underlying theme, the nature of relationship, that is, the state of extensions and connections between humanity, nature, and God. This in itself is not new to Thomas's work. But where previously the state of those relations for 
Thomas was predominantly elusive and broken, and the poetry a cry in desperation or anger emanating from that brokenness, the poems in Destinations reflect a definite healing of the wound. There is little desperation or anger here, little blindness and searching. These poems concern a wider vision of the connections between humanity, nature, and God which were once so acutely obscure, a return to wholeness, a 'crafting between the whole and the parts', a sanctification of the secular, a knitting together of worlds. More than that, they are expressions of the very invincibility of these relationships, making the collection as a whole strangely redolent of new hope.

\section{Notes}

1 Justin Wintle in his study of Thomas, Furious Interiors (1996), suggests not only that Honest to God is a 'useful introduction to contemporary Anglican thought' but that it also 'indicates the extent to which R. S. Thomas's "personal" search for God has been undertaken within a definable theological context' (415).

2 This in contrast to Buuren, who sees the mythic poems as Thomas's deliberate attempt to 'do away for ever with the theistic God, who simply cannot be the way people traditionally believe he is' (1993: 110). While clearly Thomas is expanding in a radical way more traditional images of deity, to see the mythic poems merely as a means of destroying the old to make way for the new seems to deny them, and the religious poems as a whole, a deeper complexity as multidimensional and paradoxical manifestations, simultaneously ironic and sincere, destroying and amalgamating.

3 Echoing this point, R. L. Brett, in his book Faith and Doubt: Religion and Secularisation in Literature from Wordsworth to Larkin (1997), indicates a similar shift in emphasis in contemporary religious sensibility from merely exterior forms of devotion to just such an interior and contemplative exploration, from spiritual stasis, as it were, to spiritual development, from religion as 'received' or even 'achieved' truth, to an emphasis on spiritual search characterised by uncertainty and even existential angst (157-8).

4 For a more detailed argument on this point see my article 'Reality and the Dream in the Recent Poetry of R. S. Thomas' New Welsh Review 44, (spring 1999).

5 This practice of subjective artistic unification was central to the so-called 'New Apocalypse' poets of the 1940 s who took their name from D. H. Lawrence's Apocalypse (1939), a 'radical critique of cultural and religious orthodoxy', and whose principal practitioner was Dylan Thomas (Stringer 1996: 485).

6 Buuren discusses Thomas's religious poetry as reflective of ascending stages of prayer, from dialogue to monologue to, finally, silence and waiting as 'the ultimate alternative' (1993: 140-1).

7 Such neglect is due, at least in part, to the fact that Destinations was issued in a special, limited edition of only three hundred copies by the Celandine Press. The volume went, and continues to go, virtually unnoticed amongst critics, who have taken to the more obvious volumes of Thomas's Rhiw period, such as 
Experimenting with an Amen (1986) and The Echoes Return Slow (1988), and yet the exquisite production of the book and Thomas's republication of many of the poems in later collections both indicate Destinations to be a work of some importance for the poet.

8 'The Other', while perhaps most widely known by its later inclusion in Thomas's 1988 collection The Echoes Return Slow, was originally published in Destinations. 